\title{
Pain management in the emergency department: a clinical review
}

\author{
Sergey M. Motov ${ }^{1}$, Katherine Vlasica ${ }^{2}$, Igor Middlebrook ${ }^{2}$, \\ Alexis LaPietra² \\ 'Department of Emergency Medicine, Maimonides Medical Center, Brooklyn, NY, USA \\ ${ }^{2}$ Department of Emergency Medicine, St. Joseph's Hospital and Medical Center, Patterson, NJ, USA
}

Pain is one of the most common reasons for patients to visit the emergency department. The ever-growing research on emergency department analgesia has challenged the current practices with respect to the optimal analgesic regimen for acute musculoskeletal pain, safe and judicious opioid prescribing, appropriate utilization of non-opioid therapeutics, and non-pharmacological treatment modalities. This clinical review is set to provide evidence-based answers to these challenging questions.

Keywords Pain; Pain management; Emergency service, hospital; Analgesics, opioids
eISSN: $2383-4625$

Received: 14 September 2021 Revised: 1 November 2021

Accepted: 3 Noverber 2021

Correspondence to: Sergey M. Motov Department of Emergency Medicine, Maimonides Medical Center, 4802 Tenth Avenue, Brooklyn, NY 11219, USA E-mail:smotov@maimonidesmed.org ORCID

https://orcid.org/0000-0002-9668-216X

\section{Capsule} Summary

\section{What is already known}

Pain is one of the most common reasons for patients to visit the emergency department (ED). Due to the extensive number of visits to the ED related to pain, emergency medicine physicians and mid-level providers should be experts in providing safe, effective, and timely pain management.

What is new in the current study

This focused clinical review is set to provide evidence-based answers to the following questions: What is the optimal analgesic treatment for musculoskeletal pain that includes ibuprofen, acetaminophen, and opioids? When are opioids indicated and which drug(s), dose(s), and routes of administration are preferred? What is the role of non-opioid alternatives for managing pain in the ED? Is over-the-counter topical lidocaine 4\% patch as good as prescription $5 \%$ lidocaine patch? What non-pharmacological interventions alleviate pain in the $E D ?$ 


\section{INTRODUCTION}

Pain is one of the most common reasons for patients to visit the emergency department (ED). ${ }^{1}$ Due to the extensive number of visits to the ED related to pain, emergency medicine (EM) physicians and midlevel providers should be experts in providing safe, effective, and timely pain management. Given the ongoing opioid epidemic across the country, EM clinicians are uniquely positioned to combat this crisis by broader utilization of non-opioid analgesia, thoughtful prescribing of parenteral and oral opioids in the ED and at discharge and identifying and treating patients with opioid use disorder in the ED. ${ }^{2}$ The research related to ED analgesia has grown exponentially over the past 10 years, frequently challenging dogmatic approaches to pain and numerous current pain management practices.

This focused clinical review is set to provide evidence-based answers to the following questions: What is the optimal analgesic treatment for musculoskeletal (MSK) pain that includes ibuprofen, acetaminophen, and opioids? When are opioids indicated and which drug(s), dose(s), and routes of administration are preferred? What is the role of non-opioid alternatives for managing pain in the ED? Is over-the-counter topical lidocaine 4\% patch as good as prescription 5\% lidocaine patch? What non-pharmacological interventions alleviate pain in the ED?

\section{WHAT IS THE OPTIMAL ANALGESIC TREATMENT FOR MSK PAIN?}

Non-opioid therapeutic agents (acetaminophen and non-steroidal anti-inflammatory drug [NSAID]'s) and opioids are frequently administered in combinations in the ED and at discharge for patients with MSK and soft tissue injuries (STIs) pain due to synergistic effects on pain relief. ${ }^{2,3}$ The efficacy of combination therapies and analgesic superiority of a single class has been challenged recently by numerous clinical trials. A combination of acetaminophen $(1 \mathrm{~g})$ and ibuprofen $(400 \mathrm{mg}$ ) has been found to lack analgesic and functional superiority over ibuprofen alone in managing acute MSK pain and back pain. ${ }^{4,5}$ Similarly, this combination was not better than paracetamol (acetaminophen) alone in ED patients with minor acute MSK injuries. ${ }^{6}$ The ibuprofen/acetaminophen combination was found to be as effective as oxycodone/acetaminophen, hydrocodone/acetaminophen, and codeine/acetaminophen for short-term pain relief (up to 2 hours) in ED patients with acute MSK pain including fractures. ${ }^{7}$ A head-to-head comparison of NSAID's (valdecoxib) to an opioid/acetaminophen combination demonstrated similar pain relief for short-term analgesia (up to 60 minutes) in ED patients with acute MSK. ${ }^{8}$
In patients with acute STIs (sprain, strain, or joint, ligament, tendon, or muscle contusion), NSAID's provided similar analgesic efficacy to acetaminophen at 1 to 2 hours and at 2 to 3 days (high certainty evidence), and to opioids at one hour (moderate certainty evidence) and at 4 to 7 days (low-certainty evidence). ${ }^{9}$ Similarly, oral paracetamol (acetaminophen), ibuprofen or a combination of both resulted in similar analgesic efficacy at the initial 2 hours and in the first 3 days in ED patients with mild to moderate STI pain. ${ }^{10}$

Based on available evidence, oral acetaminophen or ibuprofen administered alone are equally effective for initial pain management in the ED and up to 2 to 3 days post-discharge in ED patients presenting with acute MSK and STI painful conditions. Patients with acute fracture might require a short 2 to 3 day course of opioids.

\section{WHEN ARE OPIOIDS INDICATED AND WHICH DRUG(S), DOSE(S), AND ROUTES OF ADMINISTRATION ARE PREFERRED?}

Opioids exert their clinical analgesic effect by binding to the opioid receptors (mu, delta, kappa) in the brain, spinal cord, and peripheral nervous system. ${ }^{11}$ Parenteral and oral opioids are effective in controlling a variety of acute painful conditions of moderate to severe intensity. ${ }^{11,12}$ However, a balance between the benefits and harms related to opioids should be thoughtfully considered prior to initiating opioid therapy in the ED. ${ }^{3,12}$ The current opioid epidemic has led to several challenges in opioid administration, including optimal opioid selection, dosing regimen, and route in the ED and at discharge. ${ }^{3,13}$

\section{Indications}

Opioid analgesics provide rapid and effective pain relief to patients presenting to the ED with a variety of acute painful syndromes, several chronic painful syndromes, and cancer-related pain syndromes (Table 1). ${ }^{11}$ Opioids should be used in the ED as a part of multimodal analgesia in conjunction with non-pharmacological and non-opioid therapies when the likelihood of their analgesic benefit is judged to exceed the likelihood of harm. ${ }^{12}$ Opioids should not be used as first-line analgesics in the ED or at discharge in patients with acute back pain, ${ }^{14}$ acute headache, ${ }^{15-17}$ acute MSK pain (with the exception of fractures), ${ }_{1}^{7}$ and acute dental pain ${ }^{18}$ as the risks associated with their use (misuse, overdose, addiction) are significantly higher than the marginal, if any, pain relief provided.

Data supporting the use of opioids in the ED for treatment of acute exacerbation of chronic, non-cancer pain demonstrates 
Table 1. Indications for opioid administration in the ED

\begin{tabular}{|c|c|c|}
\hline Setting & Pain type & Examples \\
\hline \multirow[t]{9}{*}{ In the ED } & Acute pain & $\begin{array}{l}\text { Abdominal pain: appendicitis, cholecystitis, pyelonephritis, pancreatitis, bowel obstruction, diverticulitis/colitis, } \\
\text { abdominal aortic aneurysm, ovarian or testicular torsion, ectopic (ruptured or unruptured) pregnancy, mesenteric ischemia }\end{array}$ \\
\hline & & Acute coronary syndrome (fentanyl) \\
\hline & & Flank pain: pyelonephritis, renal colic \\
\hline & & Traumatic musculoskeletal pain: fractures, dislocations, tendon/muscle tear/rupture, meniscal tear \\
\hline & & Polytrauma: musculoskeletal, visceral \\
\hline & & Cutaneous pain: burns, phlegmons, large lacerations, extensive cellulitis \\
\hline & & Vascular/ischemic pain: aortic dissection, limb/mesenteric ischemia, gangrene \\
\hline & Chronic pain & Vaso-occlusive crisis of sickle cell disease \\
\hline & & Cancer pain \\
\hline \multirow{4}{*}{$\begin{array}{l}\text { At discharge-short } \\
\text { (up to } 3 \text { days) } \\
\text { course }\end{array}$} & Acute pain & Abdominal pain: traumatic (hematoma, traumatic wounds), biliary colic \\
\hline & & Flank pain: pyelonephritis, renal colic \\
\hline & & Traumatic musculoskeletal pain: fractures, tendon/muscle tear/rupture, meniscal tear \\
\hline & & Cutaneous pain: burns, large lacerations \\
\hline
\end{tabular}

$E D$, emergency department.

Table 2. Dosing, routes, and clinical properties of commonly used opioids in the ED

\begin{tabular}{|c|c|c|}
\hline Opioid & Dose and route & Clinical properties \\
\hline Morphine & $\begin{array}{l}\text { Intravenous, subcutaneous: Weight-based: } 0.05-0.1 \mathrm{mg} / \mathrm{kg} \\
\text { Fixed: } 4-6 \mathrm{mg} \\
\text { Inhalation (nebulized): } 10-20 \mathrm{mg} \text { (per dose) } \\
\text { Oral: } 7.5-10 \mathrm{mg} \text { (opioid-naïve patients) }\end{array}$ & $\begin{array}{l}\text { Hydrophilic-slower penetration through BBB } \\
\text { Less euphoric, more dysphoric } \\
\text { Leads to histamine release } \\
\text { Severely emetogenic }\end{array}$ \\
\hline Hydromorphone & $\begin{array}{l}\text { Intravenous, subcutaneous: Weight-based: } 0.005-0.01 \mathrm{mg} / \mathrm{kg} \\
\text { Fixed: } 0.5-1 \mathrm{mg} \text { dose } \\
\text { Intranasal (via MAD): } 1-2 \mathrm{mg} \text { (per dose) } \\
\text { Oral: } 1-2 \mathrm{mg} \text { (opioid-naïve patients) }\end{array}$ & $\begin{array}{l}8 \text { times more potent and } 10 \text { times more lipophilic (parenteral route) than morphine } \\
\text { Faster penetration through BBB } \\
\text { Severely euphoric with high potential for abuse, misuse and diversion-prone } \\
\text { Higher rates of respiratory and CNS depression }\end{array}$ \\
\hline Fentanyl & $\begin{array}{l}\text { Intravenous } \\
\text { Weight-based: } 0.5-1 \mu \mathrm{g} / \mathrm{kg} \\
\text { Fixed: } 25-75 \mu \mathrm{g} \text { per dose } \\
\text { Inhalation (nebulized): } 2-4 \mu \mathrm{g} / \mathrm{kg} \\
\text { Intranasal (via MAD): } 1-1.5 \mu \mathrm{g} / \mathrm{kg} \\
\text { Transmucosal (Iollypop)-in the ED only: } 15-25 \mu \mathrm{g} \\
\text { Buccal (rapidly dissolvable tablets)-in the ED only: 100-200 } \mu \mathrm{g} \\
\quad \text { (per tablet) }\end{array}$ & $\begin{array}{l}100 \text { times more potent and } 600 \text { times more lipophilic than morphine } \\
\text { Fastest penetration through BBB } \\
\text { Highest euphorigenic potential }\end{array}$ \\
\hline Oxycodone & Oral: $5 \mathrm{mg}$ & Highest oral bioavailability \\
\hline $\begin{array}{l}\text { Oxycodone/ } \\
\text { acetaminophen }\end{array}$ & Oral: $5 \mathrm{mg} / 325 \mathrm{mg}$ & $\begin{array}{l}\text { Fast penetration through } \mathrm{BBB} \\
\text { Severely euphorigenic with great potential of misuse, abuse and diversion } \\
\text { Lowest effective dose to be used in the ED and at discharge }\end{array}$ \\
\hline $\begin{array}{l}\text { Hydrocodone/ } \\
\text { acetaminophen }\end{array}$ & & $\begin{array}{l}\text { Prodrug, active metabolite is hydromorphone } \\
\text { Euphorigenic, abuse and misuse prone }\end{array}$ \\
\hline Tramadol & & $\begin{array}{l}\text { Prodrug, active metabolite is } 0 \text {-desmethyltramadol (M1), which is a more potent } \\
\text { analgesic. } \\
\text { Dual mode of action: inhibition of re-uptake of Norepinephrine/ Serotonin and mu- } \\
\text { receptor agonism } \\
\text { Euphorigenic, abuse and misuse prone }\end{array}$ \\
\hline Codeine & Oral: $7.5 \mathrm{mg}, 15 \mathrm{mg}, 30 \mathrm{mg}$ & Prodrug, one of the active metabolites is morphine \\
\hline Tylenol/codeine & Oral: $325 \mathrm{mg} / 7.5 \mathrm{mg}, 325 \mathrm{mg} / 15 \mathrm{mg}, 325 \mathrm{mg} / 30 \mathrm{mg}$ & $\begin{array}{l}\text { Weak analgesic } \\
\text { Great genetic variability to response based on metabolism } \\
\text { Limited data on addictive potential (related to morphine) }\end{array}$ \\
\hline
\end{tabular}

ED, emergency department; BBB, blood-brain barrier; MAD, mucosal atomization device; CNS, central nervous system. 
higher likelihood of harm rather than benefit. ${ }^{19}$ Opioid analgesics should not be routinely used in the ED for chronic non-cancer pain with a notable exception of vaso-occlusive crisis of sickle cell disease. ${ }^{20}$

\section{Choice of opioids}

ED clinicians must recognize that commonly used opioids in the ED significantly differ from each other with respect to their ability to induce euphoria potentially leading to addiction (Table 2). ${ }^{21}$ Based on the available evidence, morphine sulfate administered either parenterally or orally in the ED and at discharge provides better balance of adequate analgesia and reduced euphoria and should be considered as the opioid of choice. In the situation when morphine is contraindicated and opioid analgesia is still warranted, parenteral fentanyl and oral hydrocodone are suitable alternatives in the ED and at discharge. ${ }^{11,12}$ Parenteral and oral hydromorphone should be avoided as a first line opioid in the ED due to increased rates of respiratory and central nervous system depression (compared to morphine) as well as due to severe euphorigenic properties. ${ }^{22,23}$ Oxycodone should not be used in the ED or at discharge due to greater potential for misuse, diversion, overdose, and the development of addiction with a lack of analgesic superiority to morphine and hydrocodone. ${ }^{21,24}$ Similarly, tramadol should not be used in the ED and at discharge due to its modest, at best, analgesic efficacy, high potential for misuse, and host of numerous adverse effects (e.g., hypoglycemia, hyponatremia, seizures, serotonergic syndrome). ${ }^{11,21}$ Lastly, codeine plays no role in managing pain in the ED as it provides sub-optimal pain relief with significant genetic variability in analgesic response. ${ }^{11,21}$

\section{Dosing ranges and routes of administration}

Pure mu-receptor agonists lack an analgesic ceiling, and their doses can be titrated upwards until pain is controlled, or side effects become intolerable or dangerous." Parenteral opioid administration via an intravenous (IV) route achieves rapid, titratable, and effective pain relief in the ED and serves as a preferred route of opioid delivery., ${ }^{3,11}$ When intravascular access is not readily available, ED clinicians should consider administration of opioids via intranasal (IN) route (fentanyl, hydromorphone), inhalation (via nebulizer) route (fentanyl, morphine), subcutaneous injection (morphine, hydromorphone), or transmucosal route (rapidly dissolvable fentanyl tablets). ${ }^{3}$ Intramuscular (IM) delivery of opioids in the ED should be avoided as it is associated with severe pain at the injection site, unpredictable absorption rates, soft tissue infection, and myofibrosis leading to a dose escalation and higher rates of adverse effects. ${ }^{3}$ The oral route of opioid administration in the ED should be considered when feasible, even though it re- sults in poor oral bioavailability (with the exception of oxycodone) and delayed onset of analgesia in the ED limiting its utility for rapid pain control. ${ }^{2,3,25}$

\section{WHAT IS THE ROLE OF NON-OPIOID ALTERNATIVES FOR MANAGING PAIN IN THE ED?}

A variety of non-opioid alternatives have been broadly utilized in the ED for managing numerous painful syndromes with great success supported by a large body of literature.

Ketamine is a non-competitive N-methyl-D-aspartate (NMDA)/ glutamate receptor complex antagonist and potent analgesic suitable for the management of acute and chronic pain in the ED endorsed by the American College of Emergency Physicians and the American Academy of Emergency Medicine., ${ }^{2,26}$ When administered in subdissociative (SDK) doses, the common IV dosing regimen is 0.1 to $0.3 \mathrm{mg} / \mathrm{kg}$, or a 15 to $30 \mathrm{mg}$ fixed dose administered over 15 minutes to reduce psycho-perceptual adverse effects. ${ }^{27-29}$ SDK at $0.3 \mathrm{mg} / \mathrm{kg}$ IV has been shown to have similar efficacy in comparison to morphine $0.1 \mathrm{mg} / \mathrm{kg}$ IV for managing pain in the $E D .^{28-31}$ In the absence of IV access, SDK can be administered IN at 0.5 to $1 \mathrm{mg} / \mathrm{kg}$ with analgesia similar to IM and IN administration of opioids. ${ }^{32,33}$ Additionally, nebulized ketamine at dosing range of 0.75 to $1.5 \mathrm{mg} / \mathrm{kg}$ was found to be effective in reducing acute pain in adult and pediatric ED patient with acute painful conditions. ${ }^{34}$ Recently, a randomized clinical trial of 120 patients demonstrated similar analgesic efficacy of nebulized ketamine given at three different dosing regimens: $0.75,1$, and $1.5 \mathrm{mg} / \mathrm{kg}^{3 .}$

For chronic pain management, data on SDK is limited to case reports and case series. Ketamine can be a potential choice as part of an opioid sparing strategy in patients with tolerance or opioid dependence requiring management of acute or chronic pain management. ${ }^{12}$ The current EM literature supports the administration of SDK as a safe and effective agent for use in ED pain management (Table 3).

\section{Nitrous oxide}

Nitrous oxide is a tasteless colorless gas administered in combination with oxygen via inhalation and is used as an anxiolytic, analgesic, and sedative agent. The mechanism of action involves NMDA receptor antagonism and release of endogenous opioid via opioid receptor agonism in the central nervous system. ${ }^{36}$ Nitrous oxide is administered via facemask or nasal hood, is easily titratable, and has rapid onset and elimination making it an ideal agent for pain control in the ED. ${ }^{37}$ The most common concentration is $50 \%$ to $70 \%$ nitrous oxide (30\%-50\% oxygen) via an on demand 
Table 3. Routes and dosing regimens for ketamine administration for pain in the emergency department

\begin{tabular}{|c|c|c|}
\hline Route & Dosing & Comments \\
\hline \multicolumn{3}{|l|}{ Intravenous } \\
\hline 1. Weight-based & $0.1-0.3 \mathrm{mg} / \mathrm{kg}$ over $15-30$ minutes & Avoid IV push dose (higher rates of psycho-perceptual adverse effects) \\
\hline 3. Continuous infusion & $0.1-0.15 \mathrm{mg} / \mathrm{kg} / \mathrm{hr}$ & \\
\hline \multirow[t]{2}{*}{ Intranasal } & $0.7-1 \mathrm{mg} / \mathrm{kg}$ & Adult patients might require higher concentrations of ketamine \\
\hline & & Max dose per nostril- $1 \mathrm{~mL}$ \\
\hline 1. Weight-based & $0.1-0.3 \mathrm{mg} / \mathrm{kg}$ & Slower onset of analgesic than IV route \\
\hline 2. Fixed & $15-20 \mathrm{mg}$ & Titrate infusion up by $2.5-5 \mathrm{mg}$ every $30-60$ minutes \\
\hline 3. Continuous infusion & $0.1-0.15 \mathrm{mg} / \mathrm{kg} / \mathrm{hr}$ & \\
\hline \multirow[t]{2}{*}{ Inhalation } & $0.75-1.5 \mathrm{mg} / \mathrm{kg}$ & Titratable \\
\hline & & Consider using breath-actuated nebulizer \\
\hline Oral & $0.25-0.5 \mathrm{mg} / \mathrm{kg}$ & Bitter taste, consider adding sweetener \\
\hline
\end{tabular}

IV, intravenous.

Table 4. Indications and contraindications for emergency medicine nitrous oxide use

\begin{tabular}{ll}
\hline Indications & \multicolumn{1}{c}{ Contraindications } \\
\hline $\begin{array}{l}\text { Lumbar puncture } \\
\text { Incision and drainage }\end{array}$ & $\begin{array}{l}\text { Severe head injury } \\
\text { Severe asthma/chronic obstructive pulmonary } \\
\text { disease } \\
\text { Pneumothorax/pneumocephalus/pneumomedi- } \\
\text { Fractures and dislocations }\end{array}$ \\
$\begin{array}{l}\text { Burns } \\
\text { Laceration repair }\end{array}$ & $\begin{array}{l}\text { First and second trimester pregnancy } \\
\text { Prehospital pain management }\end{array}$ \\
\hline
\end{tabular}

inhalation mechanism or continuous flow device. ${ }^{37,38}$ Nitrous oxide is a potent, safe, effective inhalational anesthetic that provides quick and titratable pain relief for a variety of acutely painful complaints or procedures performed in the pediatric and adult ED population ${ }^{37,38}$ (Table 4). Administration of nitrous oxide in concentrations higher than $70 \%$ or in combinations with opioids or benzodiazepines requires full cardiopulmonary monitoring. There are no fasting requirements or restrictions postadministration when nitrous oxide is given as a single agent in the ED. ${ }^{39}$

\section{Intravenous (IV) lidocaine}

Lidocaine non-competitively blocks voltage-gated sodium channels as well as NMDA receptors and reduces hyperalgesia and central sensitization. ${ }^{40}$ When administered IV at 1 to $1.5 \mathrm{mg} / \mathrm{kg}$ dose over 10 to 15 minutes, lidocaine causes minimal adverse effects (dizziness, tinnitus, periorbital and perioral numbness) that are transient and rapidly reversible. ${ }^{40,41}$ Despite promising data from the earlier studies for renal colic, $^{41}$ subsequent studies demonstrated analgesic inferiority of IV lidocaine to IV ketorolac alone and to IV ketorolac/lidocaine combination. ${ }^{42}$ Similarly, IV lidocaine failed to demonstrate significant pain relief in ED patients pre- senting with acute headache ${ }_{1}^{43}$ acute low back pain ${ }_{1}^{44}$ and abdominal pain. ${ }^{45} \mathrm{~A}$ recent systematic review found no definitive evidence to recommend IV lidocaine use and recommended further research within a larger and older population to assess the efficacy and safety in specific painful syndromes.$^{46}$ At present, IV lidocaine cannot be recommended for routine use in the ED and its administration should be based on a case by case basis.

\section{Neuroleptics (antidopaminergic medications)}

Haloperidol is a butyrophenone derivative that exerts its effects through dopamine receptor blockade (D2-R antagonist). Additionally, haloperidol binds to the histamine receptors, alpha-2 adrenergic receptors, $5 \mathrm{HT}-2$ receptors and NMDA receptors and decreases hyperalgesia produced by chronic opioid use. ${ }^{47}$ Droperidol is a butyrophenone derivative with potent dopamine D2 antagonist actions with additional actions such as A2 adrenoceptor agonist and $5 \mathrm{HT}-3$, muscarinic and nicotinic receptors antagonist. ${ }^{48}$

Haloperidol and droperidol have been used in the ED as an adjunct in treatment of headache, ${ }_{1}^{49}$ abdominal pain associated with cannabinoid hyperemesis syndrome ${ }^{50}$ gastroparesis and cyclic vomiting syndrome, ${ }^{51}$ and chronic pain not responsive to opioids. ${ }^{52}$ Traditional dosing regimens and routes include haloperidol: 2.5-5 mg IV, 5-10 mg IM; droperidol: 1.25-2.5 mg IV, 2.5-5 mg IM.

\section{Ultrasound-guided regional anesthesia}

The most common ultrasound-guided regional anesthesia (UGRA) application in the ED is for management of patients presenting with hip/femur/upper extremity fractures followed by truncal and cervico-cranial applications (Table 5). UGRA provides significant pain reduction, alleviates the need for rescue opioid analgesia, and decreases the length of stay in the ED when compared to procedural sedation with no appreciable differences in analgesic 
Table 5. Commonly performed ultrasound-guided nerve blocks in the emergency department

\begin{tabular}{|c|c|c|c|}
\hline & Clinical indications & Advantages & Pitfalls \\
\hline \multicolumn{4}{|l|}{ Upper extremity UGRA } \\
\hline Interscalene & $\begin{array}{l}\text { Shoulder dislocation } \\
\text { Lacerations to upper arm/deltoid } \\
\text { Humerus fractures }\end{array}$ & $\begin{array}{l}\text { Similar analgesic efficacy and satisfaction } \\
\text { with procedural sedation }\end{array}$ & $\begin{array}{l}\text { Avoid in patients who cannot tolerate } \\
\text { unilateral phrenic nerve paralysis } \\
\text { Avoid transverse cervical artery } \\
\text { Inconsistent block below mid humerus }\end{array}$ \\
\hline Supraclavicular & $\begin{array}{l}\text { Any upper limb injury below the shoulder } \\
\text { Abscess drainage }\end{array}$ & Broad coverage of upper limb & $\begin{array}{l}\text { Avoid in patients who cannot tolerate } \\
\text { unilateral phrenic nerve paralysis }\end{array}$ \\
\hline Infraclavicular & $\begin{array}{l}\text { Elbow dislocations } \\
\text { Forearms fractures } \\
\text { Wrist fractures }\end{array}$ & $\begin{array}{l}\text { Lesser systemic absorption } \\
\text { Low risk of phrenic nerve paralysis }\end{array}$ & Hyperacute needle approach \\
\hline Axillary & $\begin{array}{l}\text { Elbow dislocations } \\
\text { Forearms fractures } \\
\text { Wrist fractures }\end{array}$ & $\begin{array}{l}\text { Lesser systemic absorption } \\
\text { Low risk of phrenic nerve paralysis }\end{array}$ & Multiple redirections \\
\hline Median & Volar lateral hand to wrist, distal phalanx of digits $1-3$ & & \\
\hline Radial & $\begin{array}{l}\text { Distal radius fracture } \\
\text { Dorsal/lateral hand from DIP to wrist }\end{array}$ & & \\
\hline Ulnar & $\begin{array}{l}\text { Boxer's fracture } \\
\text { Lacerations to medial aspect of hand }\end{array}$ & & \\
\hline \multicolumn{4}{|l|}{ Trunk \& neck } \\
\hline Superficial cervical plexus & $\begin{array}{l}\text { IJ placement } \\
\text { Clavicle fracture } \\
\text { Neck and ear lacerations from mandible to clavicle } \\
\text { Neck abscess }\end{array}$ & $\begin{array}{l}\text { Good alternative to the traditional } \\
\text { "diamond" field ear block }\end{array}$ & $\begin{array}{l}\text { Placement too medial will reach the } \\
\text { brachial plexus }\end{array}$ \\
\hline Serratus anterior & $\begin{array}{l}\text { Rib fractures } \\
\text { Chest tube placement } \\
\text { Zoster dermatomal rash (T2-9) }\end{array}$ & $\begin{array}{l}\text { Easily performed in prone position/ } \\
\text { C-spine immobilization superficial }\end{array}$ & Patchy posterior and axillary coverage \\
\hline Erector spinae & $\begin{array}{l}\text { Rib fractures } \\
\text { Chest tube placement } \\
\text { Zoster dermatomal rash thoracic/lumbar } \\
\text { Vertebral compression fractures } \\
\text { Renal colic }\end{array}$ & $\begin{array}{l}\text { Better coverage in posterior rib fractures } \\
\text { Transverse processes provide a good } \\
\text { target and bony backdrop for safety }\end{array}$ & Pneumothorax \\
\hline $\begin{array}{l}\text { Transversus abdominus } \\
\text { plane }\end{array}$ & $\begin{array}{l}\text { Abdominal wall lacerations/abscesses below umbilicus } \\
\text { Hernia reductions } \\
\text { Zoster rashes }\end{array}$ & Simple to perform & Will not cover visceral pain \\
\hline \multicolumn{4}{|l|}{ Lower extremity } \\
\hline Fascia iliaca block & $\begin{array}{l}\text { Fractures of hip, neck, shaft of femur } \\
\text { Abscess/lacerations anterior thigh } \\
\text { Hip dislocations }\end{array}$ & $\begin{array}{l}\text { Performing this block above the inguinal } \\
\text { ligament produces higher success rates }\end{array}$ & \\
\hline $\begin{array}{l}\text { Pericapsular nerve group } \\
\text { block }\end{array}$ & $\begin{array}{l}\text { Intracapsular hip fractures } \\
\text { Pubic rami fractures } \\
\text { Acetabular fractures }\end{array}$ & $\begin{array}{l}\text { Motor sparing } \\
\text { Low risk of intravascular injection } \\
\text { Low volume } \\
\text { Good bony backdrop for safety }\end{array}$ & \\
\hline Femoral nerve & $\begin{array}{l}\text { Femoral shaft fractures } \\
\text { Patella fractures/dislocations } \\
\text { Proximal tibia fractures } \\
\text { Abscess/lacerations anterior thigh }\end{array}$ & Good vascular landmark & $\begin{array}{l}\text { Intravascular injection } \\
\text { Injection above fascia iliaca }\end{array}$ \\
\hline $\begin{array}{l}\text { Sciatic nerve at popliteal } \\
\text { fossa }\end{array}$ & $\begin{array}{l}\text { Leg, ankle and foot fractures/dislocations } \\
\text { Spares medial malleolus and medial leg }\end{array}$ & $\begin{array}{l}\text { "Spinal of the leg" } \\
\text { Tilt probe to the toes for optimal anisotropy }\end{array}$ & $\begin{array}{l}\text { Compartment syndrome controversy } \\
\text { Intrafascicular injection }\end{array}$ \\
\hline Posterior tibial & $\begin{array}{l}\text { Lacerations and foreign body to sole of foot } \\
\text { Calcaneal fracture }\end{array}$ & Good vascular landmark & \\
\hline
\end{tabular}

UGRA, ultrasound-guided regional anesthesia; DIP, distal interphalangeal joint; IJ, internal jugular.

efficacy and patient's satisfaction. Furthermore, the utilization of UGRA in geriatric patients and patients with substance use disorder may eliminate any untoward side effects of parenteral opioid medications and reduce the dose of opioids. ${ }^{53,54}$ Ultrasound guidance, calculation of maximum/lowest effective dose, aspiration before injection of 3 to $5 \mathrm{~mL}$ aliquots of local anesthetic of choice, 
and hydrolocation of structures with sterile saline at the start of infiltration are recommendations to prevent UGRA-related complications including local anesthetic systemic toxicity (LAST). ${ }^{55}$

An IV lipid emulsion (intralipid) therapy should be readily available when using UGRA to manage a LAST. Symptoms of LAST are typically progressive, from minor (tongue, perioral numbness, restlessness, muscle fasciculations, hypertension, tachycardia) to moderate (seizures, global central nervous system depression/confusion) to signs of impending cardiovascular collapse (bradycardia, conduction block, hypotension). ${ }^{56}$

If the patient is above $70 \mathrm{~kg}$, an initial bolus of $100 \mathrm{~mL} 20 \%$ lipid emulsion should be administered over 2 to 3 minutes followed by a $20 \%$ lipid emulsion infusion of 200 to $250 \mathrm{~mL}$ over 15 to 20 minutes. For patients below $70 \mathrm{~kg}$, the bolus dose is a weightbased $1.5 \mathrm{~mL} / \mathrm{kg}$ followed by a $0.25 \mathrm{~mL} / \mathrm{kg} / \mathrm{min}$ infusion. If circulatory stability is not attained, rebolusing up to two further times and increasing the infusion to $0.5 \mathrm{~mL} / \mathrm{kg} / \mathrm{min}$ is suggested. The maximum recommended dose of lipid emulsion is $12 \mathrm{~mL} / \mathrm{kg}^{57}$

\section{IS OVER-THE-COUNTER TOPICAL LIDOCAINE 4\% PATCH AS GOOD AS PRESCRIPTION 5\% LIDOCAINE PATCH?}

Topical lidocaine has been used in patients with herpetic neuralgia, diabetic polyneuropathy, osteoarthritis, and MSK pain including low back pain. ${ }^{58,59}$ Its use is contraindicated in patients with hypersensitivity to amide anesthetics, open wounds, and skin eczema. The most common adverse effects include skin erythema, edema, and occasional burning at the application site..$^{58,59}$ The dosing regimens are 1 to 3 patches daily with a 12-hour free period with a maximum dose of three patches daily. ${ }^{58}$ A $5 \%$ topical lidocaine plaster was found to be more effective than capsaicin, gabapentin, pregabalin, and placebo and with fewer adverse effects in patients with postherpetic neuralgia. ${ }^{60}$ However, the cost of a pack of six patches that ranges from 45 to 150 US dollars in the US is prohibitive for the majority of patients..$^{61,62}$ In contrast, overthe-counter $4 \%$ lidocaine patch with average cost (pack of 6) of 6 to 12 US dollars might represent a suitable alternative as it was found to be non-inferior to the 5\% patch with respect to efficacy, side effects, and impact on quality of life..$^{61,62}$

\section{WHAT NON-PHARMACOLOGICAL INTERVENTIONS ALLEVIATE PAIN IN THE ED?}

ED pain management for the most part heavily depends on pharmacological pain management where benefits of the pain relief must be carefully balanced against the adverse effects. Non-pharmacological pain management modalities are often effective in alleviating pain in the ED despite the limited number of studies with small sample sizes. ${ }^{63}$

\section{Cryotherapy}

Multiple mechanisms have been proposed to explain the physiological basis for cryotherapy effectiveness, including inhibition of nociceptors, reducing the metabolic enzymatic activity of the injured tissue, and decreasing the nerve conduction velocity. ${ }^{64}$ Cryotherapy is frequently used for managing acute MSK and soft tissue painful syndromes. ${ }^{65-68}$ A common ED practice of applying a cold pack or ice pack to the skin with 10 minutes on, 10 minutes off can result in rapid analgesia in the ED and outpatient setting. ${ }^{66}$ Another technique such as intensive targeted cryotherapy (wetted crushed ice in the plastic bag) was found to produce lower skin temperature than the application of the cold pack ${ }^{67}$ and recently, has demonstrated more effective analgesia than chemical cold packs for acute MSK injuries in the ED. ${ }^{66}$ Cryotherapy has been shown to be effective in the treatment of low back pain, neck pain, and a multitude of other sports-related injuries. ${ }^{66-69}$

\section{Heat therapy}

When used in the context of a multimodal pain management, application of heat has shown moderate benefit in improving pain associated with acute neck and back strain in the ED. ${ }^{70}$ Use of heat packs for treatment of chronic neck pain in the elderly population has been shown to decrease pain and improve range of motion. ${ }^{71}$ Use of superficial heat was shown to be beneficial for the treatment of pain associated with temporomandibular disorders. ${ }^{72}$

A systematic review provided tentative evidence that transcutaneous electrical nerve stimulation (TENS) provided mild to moderate improvement in acute pain (back pain, fractures, headache, MSK pain, and procedural pain) as a stand-alone treatment modality in adult patients. The evidence suffered from high risk of bias and inadequate sample sizes. ${ }^{73}$ Specifically to the ED, in a single center pilot study, TENS was found to be effective (average pain relief by $40 \%$ from the baseline) in $99 \%$ of patients with a variety of acute and chronic painful conditions, and to result in functional improvement in $83 \%$ of patients. ${ }^{74}$ At present, however, robust data is lacking to support widespread use of TENS in the ED setting.

\section{Acupuncture}

The evidence for acupuncture is markedly heterogeneous, with a dearth of large, well designed, randomized controlled trials pri- 
marily supporting its use for chronic painful syndromes (back pain, osteoarthritis, and headache). ${ }^{75}$ Data on utilization of acupuncture (battlefield acupuncture) in the ED is limited with preliminary case series and smaller pilot studies showing promising results for pain control ${ }^{76}$ but with larger, randomized studies demonstrating markedly mixed outcomes ${ }^{77,78}$ that do not support widespread use of acupuncture in the ED.

\section{Osteopathic manipulative treatment}

Osteopathic manipulative treatment (OMT) is therapeutic maneuvers employed by osteopathic physicians to address dysfunctions in the MSK, myofascial, lymphatic, vascular or neurological structures. Studies looking at the application of OMT in the ED demonstrate analgesic improvement in MSK painful syndrome, reduction in the amount of parenteral analgesia ${ }^{79,80}$ and decrease in length of stay. ${ }^{81}$ However, there is a significant lack of large, randomized controlled trials. OMT is reimbursable as a procedure via five distinct codes in the American Medical Associations Current Procedural Terminology, making the utilization of this low risk ${ }_{1}^{79}$ non-pharmacologic intervention more palatable in the hands of an OMT trained emergency physicians.

\section{CONCLUSION}

ED clinicians have a great responsibility to alleviate pain by all available means in a timely, efficient, and safe manner. The improved knowledge and set of skills of ED clinicians in managing pain have led to broader utilization of non-pharmacological and non-opioid treatment modalities as well as refined and judicious use of opioids. ED clinicians are uniquely positioned to perfect patient-centered, pain syndrome-targeted analgesia by relying on and incorporating evidence-based pain management into their daily practice.

\section{CONFLICT OF INTEREST}

No potential conflict of interest relevant to this article was reported.

\section{REFERENCES}

1. Chang HY, Daubresse M, Kruszewski SP, Alexander GC. Prevalence and treatment of pain in EDs in the United States, 2000 to 2010. Am J Emerg Med 2014;32:421-31.

2. Motov $S$, Strayer $R$, Hayes $B D$, et al. The treatment of acute pain in the emergency department: a white paper position statement prepared for the American Academy of Emergency
Medicine. J Emerg Med 2018;54:731-6.

3. Motov SM, Nelson LS. Advanced concepts and controversies in emergency department pain management. Anesthesiol Clin 2016;34:271-85.

4. Bondarsky EE, Domingo AT, Matuza NM, Taylor MB, Thode HC $\mathrm{Jr}$, Singer AJ. Ibuprofen vs acetaminophen vs their combination in the relief of musculoskeletal pain in the ED: a randomized, controlled trial. Am J Emerg Med 2013;31:1357-60.

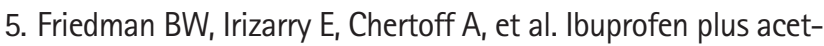
aminophen versus ibuprofen alone for acute low back pain: an emergency department-based randomized study. Acad Emerg Med 2020;27:229-35.

6. Gong J, Colligan M, Kirkpatrick C, Jones P. Oral paracetamol versus combination oral analgesics for acute musculoskeletal injuries. Ann Emerg Med 2019;74:521-9.

7. Chang AK, Bijur PE, Esses D, Barnaby DP, Baer J. Effect of a single dose of oral opioid and nonopioid analgesics on acute extremity pain in the emergency department: a randomized clinical trial. JAMA 2017;318:1661-7.

8. Lovell SJ, Taira T, Rodriguez E, Wackett A, Gulla J, Singer AJ. Comparison of valdecoxib and an oxycodone-acetaminophen combination for acute musculoskeletal pain in the emergency department: a randomized controlled trial. Acad Emerg Med 2004;11:1278-82.

9. Jones P, Lamdin R, Dalziel SR. Oral non-steroidal anti-inflammatory drugs versus other oral analgesic agents for acute soft tissue injury. Cochrane Database Syst Rev 2020;8:CD007789.

10. Hung KK, Graham CA, Lo RS, et al. Oral paracetamol and/or ibuprofen for treating pain after soft tissue injuries: single centre double-blind, randomised controlled clinical trial. PLoS One 2018;13:e0192043.

11. Wightman RS, Perrone J. Opioids. In: Strayer R, Motov S, Nelson $\mathrm{L}$, editors. Pain and procedural sedation in acute care [Internet]. painandpsa.org; 2018 [cited 2021 Sep 13]. Available from: https://painandpsa.org/opioids/.

12. Strayer RJ, Motov SM, Nelson LS. Something for pain: responsible opioid use in emergency medicine. Am J Emerg Med 2017; 35:337-41.

13. American College of Emergency Physicians Clinical Policies Subcommittee (Writing Committee) on Opioids, Hatten BW, Cantrill SV, et al. Clinical policy: critical issues related to opioids in adult patients presenting to the emergency department. Ann Emerg Med 2020;76:e13-39.

14. Friedman BW, Dym AA, Davitt M, et al. Naproxen with cyclobenzaprine, oxycodone/acetaminophen, or placebo for treating acute low back pain: a randomized clinical trial. JAMA 2015;314:1572-80. 
15. Orr SL, Friedman BW, Christie S, et al. Management of adults with acute migraine in the emergency department: the American Headache Society Evidence Assessment of Parenteral Pharmacotherapies. Headache 2016;56:911-40.

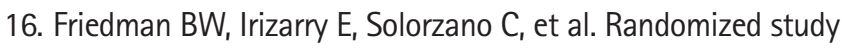
of IV prochlorperazine plus diphenhydramine vs IV hydromorphone for migraine. Neurology 2017;89:2075-82.

17. Friedman B, Monteith T. Despite variations, evidence provides clear road map for adult patients presenting with acute migraine. ED Manag 2017;29:31-3.

18. Patel NA, Afshar S. Addressing the high rate of opioid prescriptions for dental pain in the emergency department. Am J Emerg Med 2018;36:138-9.

19. Busse JW, Wang L, Kamaleldin M, et al. Opioids for chronic noncancer pain: a systematic review and meta-analysis. JAMA 2018;320:2448-60.

20. Fiocchi J, Urits I, Orhurhu V, et al. A comprehensive review of the treatment and management of pain in sickle cell disease. Curr Pain Headache Rep 2020;24:17.

21. Connors NJ, Mazer-Amirshahi M, Motov S, Kim HK. Relative addictive potential of opioid analgesic agents. Pain Manag 2021;11:201-15.

22. Beaudoin FL, Merchant RC, Janicki A, McKaig DM, Babu KM. Preventing iatrogenic overdose: a review of in-emergency department opioid-related adverse drug events and medication errors. Ann Emerg Med 2015;65:423-31.

23. Mazer-Amirshahi M, Motov S, Nelson LS. Hydromorphone use for acute pain: misconceptions, controversies, and risks. J Opioid Manag 2018;14:61-71.

24. Remillard D, Kaye AD, McAnally H. Oxycodone's unparalleled addictive potential: is it time for a moratorium? Curr Pain Headache Rep 2019;23:15.

25. Kestenbaum MG, Vilches A0, Messersmith $\mathrm{S}$, et al. Alternative routes to oral opioid administration in palliative care: a review and clinical summary. Pain Med 2014;15:1129-53.

26. American College of Emergency Physicians policy statement: sub-dissociative dose ketamine for analgesia [Internet]. Dallas, TX: American College of Emergency Physicians; 2017 [cited 2021 Jan 1]. Available from: https://www.acep.org/globalassets/new-pdfs/policy-statements/sub-dissociative-dose-ketamine-for-analgesia.pdf.

27. Goltser A, Soleyman-Zomalan E, Kresch F, Motov S. Short (lowdose) ketamine infusion for managing acute pain in the ED: case-report series. Am J Emerg Med 2015;33:601.

28. Motov S, Mai M, Pushkar I, et al. A prospective randomized, double-dummy trial comparing IV push low dose ketamine to short infusion of low dose ketamine for treatment of pain in the ED. Am J Emerg Med 2017;35:1095-100.

29. Ahern TL, Herring AA, Miller S, Frazee BW. Low-dose ketamine infusion for emergency department patients with severe pain. Pain Med 2015;16:1402-9.

30. Beaudoin FL, Lin C, Guan W, Merchant RC. Low-dose ketamine improves pain relief in patients receiving intravenous opioids for acute pain in the emergency department: results of a randomized, double-blind, clinical trial. Acad Emerg Med 2014; 21:1193-202.

31. Lovett $S$, Reed $T$, Riggs $R$, et al. A randomized, noninferiority, controlled trial of two doses of intravenous subdissociative ketamine for analgesia in the emergency department. Acad Emerg Med 2021;28:647-54.

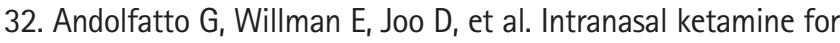
analgesia in the emergency department: a prospective observational series. Acad Emerg Med 2013;20:1050-4.

33. Shimonovich $S$, Gigi $R$, Shapira $A$, et al. Intranasal ketamine for acute traumatic pain in the emergency department: a prospective, randomized clinical trial of efficacy and safety. BMC Emerg Med 2016;16:43.

34. Drapkin J, Masoudi A, Butt M, Hossain R, Likourezos A, Motov S. Administration of nebulized ketamine for managing acute pain in the emergency department: a case series. Clin Pract Cases Emerg Med 2020;4:16-20.

35. Dove D, Fassassi C, Davis A, et al. Comparison of nebulized ketamine at three different dosing regimens for treating painful conditions in the emergency department: a prospective, randomized, double-blind clinical trial. Ann Emerg Med 2021; 78:779-87.

36. Fujinaga $M$, Maze M. Neurobiology of nitrous oxide-induced antinociceptive effects. Mol Neurobiol 2002;25:167-89.

37. Herres J, Chudnofsky CR, Manur R, Damiron K, Deitch K. The use of inhaled nitrous oxide for analgesia in adult ED patients: a pilot study. Am J Emerg Med 2016;34:269-73.

38. Duchicela SI, Meltzer JA, Cunningham SJ. A randomized controlled study in reducing procedural pain and anxiety using high concentration nitrous oxide. Am J Emerg Med 2017;35: 1612-6.

39. Babl FE, Puspitadewi A, Barnett P, Oakley E, Spicer M. Preprocedural fasting state and adverse events in children receiving nitrous oxide for procedural sedation and analgesia. Pediatr Emerg Care 2005;21:736-43.

40. Golzari SE, Soleimanpour H, Mahmoodpoor A, Safari S, Ala A. Lidocaine and pain management in the emergency department: a review article. Anesth Pain Med 2014;4:e15444.

41. Soleimanpour $H$, Hassanzadeh K, Vaezi H, Golzari SE, Esfanjani RM, Soleimanpour M. Effectiveness of intravenous lido- 
caine versus intravenous morphine for patients with renal colic in the emergency department. BMC Urol 2012;12:13.

42. Motov S, Fassassi C, Drapkin J, et al. Comparison of intravenous lidocaine/ketorolac combination to either analgesic alone for suspected renal colic pain in the ED. Am J Emerg Med 2020; 38:165-72.

43. Reutens DC, Fatovich DM, Stewart-Wynne EG, Prentice DA. Is intravenous lidocaine clinically effective in acute migraine? Cephalalgia 1991;11:245-7.

44. Tanen DA, Shimada M, Danish DC, Dos Santos F, Makela M, Riffenburgh RH. Intravenous lidocaine for the emergency department treatment of acute radicular low back pain, a randomized controlled trial. J Emerg Med 2014;47:119-24.

45. Chinn E, Friedman BW, Naeem F, et al. Randomized trial of intravenous lidocaine versus hydromorphone for acute abdominal pain in the emergency department. Ann Emerg Med 2019;74:233-40.

46. E Silva LO, Scherber K, Cabrera D, et al. Safety and efficacy of intravenous lidocaine for pain management in the emergency department: a systematic review. Ann Emerg Med 2018;72: 135-44.

47. Miller AC, Khan AM, Castro Bigalli AA, et al. Neuroleptanalgesia for acute abdominal pain: a systematic review. J Pain Res 2019;12:787-801.

48. Lai PC, Huang YT. Evidence-based review and appraisal of the use of droperidol in the emergency department. Ci Ji Yi Xue Za Zhi 2018;30:1-4.

49. McCoy JJ, Aldy K, Arnall E, Petersen J. Treatment of Headache in the Emergency Department: Haloperidol in the Acute Setting (THE-HA Study): a randomized clinical trial. J Emerg Med 2020;59:12-20.

50. Lee C, Greene SL, Wong A. The utility of droperidol in the treatment of cannabinoid hyperemesis syndrome. Clin Toxicol (Phila) 2019;57:773-7.

51. Ramirez R, Stalcup P, Croft B, Darracq MA. Haloperidol undermining gastroparesis symptoms (HUGS) in the emergency department. Am J Emerg Med 2017;35:1118-20.

52. Richards JR, Richards IN, Ozery G, Derlet RW. Droperidol analgesia for opioid-tolerant patients. J Emerg Med 2011;41:38996.

53. Canders $\mathrm{CP}$, Morales DA, Sha SW. Ultrasound-guided nerve blocks in the emergency department [Internet]. Morrisville, NC: Relias Media; 2018 [cited 2021 Sep 13]. Available from: https://www.reliasmedia.com/articles/142305-ultrasoundguided-nerve-blocks-in-the-emergency-department.

54. Wilson C. Feeling blocked?: another pain management tool in the emergency department. Ann Emerg Med 2018;72:120-6.
55. Barrington MJ, Kluger R. Ultrasound guidance reduces the risk of local anesthetic systemic toxicity following peripheral nerve blockade. Reg Anesth Pain Med 2013;38:289-99.

56. El-Boghdadly K, Pawa A, Chin KJ. Local anesthetic systemic toxicity: current perspectives. Local Reg Anesth 2018;11:3544.

57. Cao D, Heard K, Foran M, Koyfman A. Intravenous lipid emulsion in the emergency department: a systematic review of recent literature. J Emerg Med 2015;48:387-97.

58. Derry S, Wiffen PJ, Kalso EA, et al. Topical analgesics for acute and chronic pain in adults: an overview of Cochrane Reviews. Cochrane Database Syst Rev 2017;5:CD008609.

59. Devers A, Galer BS. Topical lidocaine patch relieves a variety of neuropathic pain conditions: an open-label study. Clin J Pain 2000;16:205-8.

60. Wolff RF, Bala MM, Westwood M, Kessels AG, Kleijnen J. 5\% lidocaine-medicated plaster vs other relevant interventions and placebo for post-herpetic neuralgia (PHN): a systematic review. Acta Neurol Scand 2011;123:295-309.

61. LaPietra AM, Motov S. A country in crisis: opioid sparing solutions for acute pain management. Mo Med 2019;116:140-5.

62. Castro E, Dent D. A comparison of transdermal over-the-counter lidocaine 3.6\% menthol 1.25\%, Rx lidocaine 5\% and placebo for back pain and arthritis. Pain Manag 2017;7:489-98.

63. Sakamoto JT, Ward HB, Vissoci JR, Eucker SA. Are nonpharmacologic pain interventions effective at reducing pain in adult patients visiting the emergency department? A systematic review and meta-analysis. Acad Emerg Med 2018;25:940-57.

64. Algafly AA, George KP. The effect of cryotherapy on nerve conduction velocity, pain threshold and pain tolerance. Br J Sports Med 2007;41:365-9.

65. Bleakley C, McDonough S, MacAuley D. The use of ice in the treatment of acute soft-tissue injury: a systematic review of randomized controlled trials. Am J Sports Med 2004;32:25161.

66. Bleakley CM, McDonough SM, MacAuley DC, Bjordal J. Cryotherapy for acute ankle sprains: a randomised controlled study of two different icing protocols. Br J Sports Med 2006;40:700-5.

67. Dykstra JH, Hill HM, Miller MG, Cheatham CC, Michael TJ, Baker RJ. Comparisons of cubed ice, crushed ice, and wetted ice on intramuscular and surface temperature changes. J Athl Train 2009;44:136-41.

68. Leroux EJ, Kaufman EA, Kontaxis CN, Lipman GS. Intensive Cryotherapy in the Emergency Department (ICED): a randomized controlled trial. West J Emerg Med 2021;22:445-9.

69. Block JE. Cold and compression in the management of musculoskeletal injuries and orthopedic operative procedures: a 
narrative review. Open Access J Sports Med 2010;1:105-13.

70. Garra G, Singer AJ, Leno $R$, et al. Heat or cold packs for neck and back strain: a randomized controlled trial of efficacy. Acad Emerg Med 2010;17:484-9.

71. Shin HJ, Kim SH, Hahm SC, Cho HY. Thermotherapy plus neck stabilization exercise for chronic nonspecific neck pain in elderly: a single-blinded randomized controlled trial. Int J Environ Res Public Health 2020;17:5572.

72. Furlan RM, Giovanardi RS, Britto AT, Oliveira e Britto DB. The use of superficial heat for treatment of temporomandibular disorders: an integrative review. Codas 2015;27:207-12.

73. Johnson MI, Paley CA, Howe TE, Sluka KA. Transcutaneous electrical nerve stimulation for acute pain. Cochrane Database Syst Rev 2015;2015:CD006142.

74. Grover CA, McKernan MP, Close RJ. Transcutaneous electrical nerve stimulation (TENS) in the emergency department for pain relief: a preliminary study of feasibility and efficacy. West J Emerg Med 2018;19:872-6.

75. Vickers AJ, Vertosick EA, Lewith $G$, et al. Acupuncture for chronic pain: update of an individual patient data meta-analysis. $J$ Pain 2018;19:455-74.

76. Tsai SL, Fox LM, Murakami M, Tsung JW. Auricular acupunc- ture in emergency department treatment of acute pain. Ann Emerg Med 2016;68:583-5.

77. Johnston K, Bonjour T, Powell J, April MD. Battlefield acupuncture versus standard pharmacologic treatment of low back pain in the emergency department: a randomized controlled trial. J Emerg Med 2021;61:406-15.

78. Jan AL, Aldridge ES, Visser EJ, et al. Battlefield acupuncture added no benefit as an adjunct analgesic in emergency department for abdominal, low back or limb trauma pain. Emerg Med Australas 2020 Sep 23 [Epub]. https://doi.org/10.1111/ 1742-6723.13642.

79. Roberge RJ, Roberge MR. Overcoming barriers to the use of osteopathic manipulation techniques in the emergency department. West J Emerg Med 2009;10:184-9.

80. McReynolds TM, Sheridan BJ. Intramuscular ketorolac versus osteopathic manipulative treatment in the management of acute neck pain in the emergency department: a randomized clinical trial. J Am Osteopath Assoc 2005;105:57-68.

81. Ault B, Levy D. Osteopathic manipulative treatment use in the emergency department: a retrospective medical record review. J Am Osteopath Assoc 2015;115:132-7. 